\title{
Legal Protection and Awareness of Journalist's Code of Ethics in the City of Palu, Central Sulawesi Province
}

\author{
Rahmat Bakri, Awaluddin, Widyatmi Anandi \\ Lecturer on Faculty of Law, Tadulako University
}

\begin{abstract}
The national press has a strategic role as a vehicle for mass communication, disseminating information, and forming opinions. Given the role of the press, the press must obtain legal protection guarantees, and be free from interference and coercion from anywhere. The guarantee of freedom and independence of the press is a concrete manifestation of the fulfillment of the right to public information, which is guaranteed by the 1945 Constitution and supports the professionalism of press actors in carrying out their journalistic duties. An independent press will be created if journalists are protected in carrying out their roles as holders of a public mandate to obtain information. The information produced by journalists will only contribute to the benefit of the public if in carrying out their duties, a journalist obeys the journalistic code of ethics.
\end{abstract}

Keywords: legal protection, code of ethics, press

\section{INTRODUCTION}

$\mathrm{T}$ here is no doubt that a free and independent press is very important in a democracy. The press is even positioned as the fourth pillar of democracy ${ }^{1}$. Its presence is aligned with the executive, legislative, and judicial institutions known as the trias politica a la Jhon Locke and Mostesquieu. The uniqueness of the press from the trias politica institution is its position outside the standard structure of power so that it is more free and flexible in playing its role.

The enactment of Law Number 40 of 1999 concerning the Press strengthened the existence of the national press to play an important role in fulfilling the public's right to information as an instrument for developing public opinion, participation, and upholding democracy. By conveying information appropriately, accurately, and correctly, the press is expected to help uphold justice and truth, carry out supervision, correction, and suggestions for the public interest, and realize the supremacy of law and order.

Amartya Sen (Nobel winner) stated that there has never been a substantial hunger in a democracy with a relatively free press. Through the press, the public can find out various information. Meanwhile, according to Andrew Puddephatt, information is oxygen for democracy. With the mediation of the press, government affairs are disseminated to

\footnotetext{
${ }^{1}$ Dawson, 'The Achilles Heel of Democracy?'
}

the public and prevent problems related to the public from being managed in closed spaces and only known by a few people $^{2}$.

What is stated above is an ideal description of the existence of the press and its role in promoting democracy and good governance. In reality, it is still far from being burnt. The press members have realized that to bring the ideal expectations closer to empirical reality, and there is no other way but to increase the professionalism of journalists. One of the deliberate ways to improve the professionalism of journalists, since 2010, the mandatory journalist competency test (UKW) has been imposed. Natural selection to punish press institutions and unprofessional press workers is seen as inadequate in the current euphoria of freedom.

On the other hand, the freedom of the press, which the press community has fought for, has been responded to by some people with criticism and blasphemy. The press is often accused of no longer heeding the code of ethics, ignoring the principles of balance and accuracy, and is considered to tend to develop information presentations on conflicts, violence, and pornography. This condition occurs because the national press does not work in a vacuum. Press institutions grow and develop together with political, legal, and economic institutions. The press agency works together with state institutions and other social institutions ${ }^{3}$. Journalists also interact with various professions. So efforts to organize the life of the national press and efforts to improve the professionalism of journalists require improvements to be carried out simultaneously with other institutions and professions.

The term press is not foreign to the public. Talking about the press means it will involve journalistic activities. The terms press, journalism, and mass communication are often confused and have interchangeable meanings. The press is one form of mass communication, so journalism is an activity to fill it. In this era of democratization, the press has

\footnotetext{
${ }^{2}$ Wang et al., 'Empowerment through Emotional Connection and Capacity Building'.

${ }^{3}$ Congleton, 'The Institutions of International Treaty Organizations as Evidence for Social Contract Theory'.
} 
felt freedom so that the role and function of the press can be felt and enjoyed by the public ${ }^{4}$.

During this reformation period, the faucet of press freedom has been opened wide. The press has the freedom to conduct social criticism of the government. The press is free to move in reporting. Even though it is free, the press still has to be responsible for its reporting. The government also maintains control over press freedom in daily life. Press freedom in Indonesia in the reform era was marked by the issuance of Law Number 40 of 1999 concerning the Press. With this law, anyone can publish mass media. The press in the reform era need not fear losing their publishing license if they criticize officials, both civilian and military. With the Press Law, it is hoped that the mass media in Indonesia can become one of the 4 (four) pillars of democracy ${ }^{5}$.

The Indonesian press must now shift the old paradigm and must become an independent institution. The Indonesian press may occasionally work for the success of government programs or critically highlight government policies or simply assist the government. However, in various positions, it remains an institution that demands changes for the benefit of the people ${ }^{6}$.

The presence of Law Number 40 of 1999 concerning the Press is aimed at realizing press freedom, especially providing guarantees for protection for the press from any intervention in carrying out its role ${ }^{7}$. If the previous laws and regulations placed the Press Council under the control of the government, then in Law Number 40 of 1999, the Press Council was positioned as an independent institution. The government no longer dictates the Press Council by placing the Minister of Information as its chairman. The government can no longer interfere in the matter of the membership of the Press Council.

The Press Council, which is free from government interference, has a strategic role in regulating the pattern of relations between the state and the press. It is hoped that the press will no longer be a propaganda tool used to manage the socio-political order so that it is always as expected by the authorities ${ }^{8}$. This is the main objective of strengthening the Press Council, namely the realization of an independent and free press in carrying out its functions as a medium of information, education, entertainment, and social control. The design is illustrated in Article 5 paragraph (1) of Law no. 40 of 1999 concerning the press, which states that an independent Press Council is to develop press freedom and improve the lives of the national press. More clearly, Article 15 paragraph (2) letter a of the law states that the Press Council functions to "protect press freedom from interference from other parties".

\footnotetext{
${ }^{4}$ Judhariksawan, Hukum Penyiaran.

${ }^{5}$ Manan, 'Pers Bermutu'

${ }^{6}$ Susanto, Hukum Pers Di Indonesia.

${ }^{7}$ Undang-Undang, Nomor 40 Tahun 1999 tentang Pers.

${ }^{8}$ Mochtar, Lembaga Negara Independen: Dinamika Perkembangan Dan Urgensi Penataannya Kembali Pasca-Amandemen Konstitus.
}

As a vehicle for mass communication, the national press, disseminating information, and forming opinions must be able to carry out its functions and roles as well as possible, based on professional press freedom. For this reason, the press must receive legal guarantees and protection and be free from interference and coercion from anywhere ${ }^{9}$. However, it is undeniable that the presence of various laws and regulations governing the press still does not reduce the press's threat to freedom and independence. The form of intervention against the press often does not appear on the surface but is felt enough by journalists as press actors so that journalists feel less protected by the law.

Since 2015 the Press Council has conducted a Press Freedom Index survey conducted in 13 provinces. In 2016, the survey was expanded to 24 provinces. Central Sulawesi is one of the provinces that became the locus of the study in 2016. The Press Freedom Index survey conducted by the Press Council is based on three dimensions/environment, which is considered to affect the independence and development of the press. The three dimensions/environment in question are politics, economics, and law.

The results of the 2016 survey, Central Sulawesi Province occupies a somewhat free (medium) position with a total score of 61.44. The total score is the average value of the political environment score of 62.12, the score of the economic environment of 62.17 , and the score of the legal environment of 60.06. This survey shows that press freedom in Central Sulawesi Province is different from the general situation in other provinces. Where the economic environment is considered the best than the other two environments, this result also places Central Sulawesi in the 15th rank of the 24 provinces that became the locus of the survey ${ }^{10}$.

In 2017, Central Sulawesi was ranked 22 out of 30 provinces with a total score of 65.70 (somewhat free/moderate). ${ }^{11}$ In 2018, the Central Sulawesi Province Press Independence Index increased with a total score of 69.65. Although this score has increased, it is still in the somewhat free/medium grade. An important finding in the Central Sulawesi Province Press Independence Index survey in 2018 is that there are still frequent threats of violence/intimidation/harassment against the journalist profession. The perpetrators come from public officials and community elements suspected of having links with public officials in areas that are in the spotlight of the news ${ }^{12}$.

Based on preliminary data obtained from the results of the Press Council's research for 2016 to $2018,{ }^{13}$ shows that there are still so many challenges to be faced in promoting press freedom in Central Sulawesi Province. Both challenges are external (from outside the press institution) and internal

\footnotetext{
${ }^{9}$ Undang-Undang, Nomor 40 Tahun 1999 tentang Pers.

${ }^{10}$ Tim Peneliti Dewan Pers, Indeks Kemerdekaan Pers Tahun 2016.

${ }^{11}$ Tim Peneliti Dewan Pers, Indeks Kemerdekaan Pers Tahun 2017.

${ }^{12}$ Tim Peneliti Dewan Pers, Indeks Kemerdekaan Pers Tahun 2018.

${ }^{13}$ Kerjasama dengan Fakultas Hukum Universitas Tadulako, Survei Sulawesi Tengah.
} 
challenges (from the press institution itself). So referring to the results of previous studies, the Research Team conducted further research with an accentuation on aspects of legal protection for journalists and the enforcement of journalistic codes of ethics for journalists.

Aspects of legal protection are related to various regulations that are guarantees or threats in realizing press freedom, including potential threats originating from the press institution itself due to intervention in the editorial room by the owner of the capital/owner of the press company ${ }^{14}$. Upholding the journalistic code of ethics for journalists is related to the level of understanding, compliance, and awareness of each individual/journalist to apply the journalistic code of ethics consistently in carrying out their duties.

The research location was carried out in Palu City, considering that the majority of press companies and journalists working in Central Sulawesi Province are in Palu City. Likewise, professional organizations in the Press Council, such as the Indonesian Journalists Association, the Alliance of Independent Journalists, and the Indonesian Television Journalists Association (IJTI), are located in Palu City.

\section{FORMULATION OF THE PROBLEM}

In connection with the description of the background that has been described above, in this study, there are several things that the author will discuss in the problem, namely:

1. What is the legal protection for journalists in Palu City?

2. How is the understanding, compliance, and enforcement of the journalistic code of ethics for journalists in Palu City, Central Sulawesi Province?

\section{RESEARCH METHODS}

The problems that have been formulated above will be answered or solved using an empirical juridical approach. The juridical process (law is seen as a norm or das sollen), because in discussing the problem, this research uses legal materials (both written law and unwritten law or both primary legal materials and secondary legal materials). Empirical approach (law as a social, cultural or das sein reality), because this study used preliminary data obtained from the field.

In this study, the types of data collection consisted of primary data and secondary data. Primary data is data that is directly obtained from data sources in the field (field research). This preliminary data was obtained by using questionnaires and interviews. The questionnaires and interviews were addressed to the informants determined based on the purposive sampling technique, namely the technique whose determination was based on certain considerations or reasons, namely the parties directly related to the subject

\footnotetext{
${ }^{14}$ Cui and Qi, 'The Legal Construction of Personal Information Protection
} and Privacy under the Chinese Civil Code'. matter discussed. There are 3 (three) techniques that can be used in data collection techniques in empirical or field legal research, either used individually or separately or used together. The three techniques are interviews, questionnaires or questionnaires, and observation ${ }^{15}$. As for this study, the authors used 2 (two) data collection techniques, namely questionnaires and interviews.

Furthermore, secondary data is obtained by studying and reviewing library materials (literature research) in the form of legal materials, both primary legal materials, secondary legal materials, and tertiary legal materials.

\section{DISCUSSION}

The term press comes from the Dutch word percent or English press, which means to press, which refers to an ancient printing press that had to be pressed hard to produce a printed work on a sheet of paper ${ }^{16}$. In the big Indonesian dictionary, press is defined as ${ }^{17}$ :

a. Printing and publishing business;

b. Newsgathering and broadcasting business;

c. News broadcasting through newspapers, magazines, and radio;

d. People engaged in news broadcasting, and

e. News broadcasting media such as newspapers, magazines, radio, television, and films.

According to Law Number 40 of 1999 concerning the Press, the press is a social institution and vehicle for mass communication that carries out journalistic activities that include seeking, obtaining, possessing, storing, processing, and conveying information in writing, sound,, sounds and images. as well as graphic data and other forms using print media, electronic media and all types of available channels.

The press in a legal state that adheres to the notion of popular sovereignty is guaranteed legal protection for its freedom and independence as a form of fulfilling the public's right to information ${ }^{18}$. These human rights are guaranteed in Article $28 \mathrm{~F}$ of the 1945 Constitution of the Republic of Indonesia which states that everyone has the right to communicate and obtain information to develop their personal and social environment, and has the right to seek, obtain, possess, store, process, and convey information using all kinds of information. Available channels. Similarly, Article 14 of Law Number 39 of 1999 concerning Human Rights states:

1. Everyone has the right to communicate and obtain information needed to develop their personal and social environment.

2. Everyone has the right to seek, obtain, possess, store, process, and convey information using all types of available means.

\footnotetext{
${ }^{15}$ Fajar ND and Achmad, Dualisme Penelitian Hukum Normatif \& Empiri.

${ }^{16}$ Susanto, Hukum Pers Di Indonesia.

${ }^{17}$ Kemendibud, Kamus Besar Bahasa Indonesia Daring Kemendikbud.

${ }^{18}$ Chiang, 'The State and Sovereignty'.
} 
Article 8 of Law Number 40 of 1999 concerning the Press specifically stipulates that journalists receive legal protection in carrying out their professional journalists. Furthermore, in explaining the law, it is stated that the guarantee of safety of the government and the community to journalists in carrying out their functions, rights, obligations, and roles following the provisions of the applicable laws and regulations. However, the presence of various statutes and rules governing the press does not fully guarantee the freedom and independence of the press. Threats to journalists' freedom and autonomy are still common. On the other hand, the press is obliged to comply with the restrictions set out in the laws and regulations solely as a form of respect for the right to information that has been guaranteed in the Indonesian constitution.

Analysis of Legal Protection for Journalists in Palu City, Central Sulawesi Province

Considering Law no. 40 of 1999, among other things, states that press freedom is a form of people's sovereignty and is a very important element to create a democratic society, nation, and state so that freedom of expression of thoughts and opinions as stated in Article 28 of the 1945 Constitution must be guaranteed. Whereas in the life of a democratic society, nation, and state, freedom to express thoughts and opinions according to one's conscience and the right to obtain information is an essential human right, which is needed to uphold justice and truth, promote public welfare, and educate the nation's life ${ }^{19}$.

Freedom of the press is a form of popular sovereignty based on democracy, justice, and the rule of law which is guaranteed protection by law ${ }^{20}$. In order to guarantee the freedom of the press, legal protection is absolutely necessary, considering the press as a very important element in the life of a democratic society, nation, and state. In a democratic life, accountability to the people is guaranteed, a transparent state administration system functions and justice and truth are realized.

The analysis of legal protection for journalists in Palu City was obtained based on a survey/interview of 11 expert informants who had been asked to provide an assessment of 17 (seventeen) indicators, and the results of filling out the questionnaire were recapitulated to obtain an average score per indicator. These indicators determine the legal protection for journalists. The following is described descriptively for the average score given by expert informants related to legal protection for journalists in Palu City in 17 (seventeen) indicators.

\begin{tabular}{|c|c|c|c|}
\hline $\begin{array}{l}\mathrm{N} \\
\mathrm{O}\end{array}$ & INDICATOR & $\begin{array}{l}\text { AVE } \\
\text { RAG } \\
\text { E } \\
\text { VAL } \\
\text { UE } \\
\end{array}$ & $\begin{array}{l}\text { INFORMA } \\
\text { TION }\end{array}$ \\
\hline 1 & $\begin{array}{l}\text { To what extent is the editorial } \\
\text { independence from the intervention of the } \\
\text { mass media owners in news/editorial } \\
\text { policies? }\end{array}$ & 71 & GOOD \\
\hline 2 & $\begin{array}{l}\text { To what extent are journalists free to } \\
\text { choose journalists' organizations according } \\
\text { to their conscience, including the freedom } \\
\text { not to join journalists' organizations? }\end{array}$ & 91 & $\begin{array}{l}\text { VERY } \\
\text { WELL }\end{array}$ \\
\hline 3 & $\begin{array}{l}\text { To what extent do local governments, } \\
\text { political parties, and mass organizations } \\
\text { pressure journalists to influence reporting? }\end{array}$ & 68 & MEDIUM \\
\hline 4 & $\begin{array}{l}\text { To what extent do law enforcement and } \\
\text { security forces pressure journalists to } \\
\text { influence reporting? }\end{array}$ & 66 & MEDIUM \\
\hline 5 & $\begin{array}{l}\text { To what extent do press companies provide } \\
\text { assistance and defense to journalists who } \\
\text { experience legal problems related to the } \\
\text { implementation of their duties as } \\
\text { journalists? }\end{array}$ & 78 & GOOD \\
\hline 6 & $\begin{array}{l}\text { To what extent is the attention of press } \\
\text { companies to increase the capacity and } \\
\text { skills of journalists in carrying out } \\
\text { coverage with a high level of risk? }\end{array}$ & 67 & MEDIUM \\
\hline 7 & $\begin{array}{l}\text { To what extent do journalists' } \\
\text { organizations provide assistance and } \\
\text { defense to their members who are } \\
\text { experiencing legal problems related to } \\
\text { implementing their duties as journalists? }\end{array}$ & 84 & GOOD \\
\hline 8 & $\begin{array}{l}\text { To what extent does the Press Council play } \\
\text { a mediating role and resolve press disputes } \\
\text { following the principles of universal press } \\
\text { freedom? }\end{array}$ & 74 & GOOD \\
\hline 9 & $\begin{array}{l}\text { To what extent do law enforcement and } \\
\text { security forces protect journalists from } \\
\text { threats of intimidation, pressure, and } \\
\text { physical violence in various forms by non- } \\
\text { state forces to influence or because of the } \\
\text { content of the news? }\end{array}$ & 53 & BAD \\
\hline 10 & $\begin{array}{l}\text { To what extent is the professionalism of } \\
\text { law enforcement officers in responding } \\
\text { and processing cases related to journalists } \\
\text { as a profession protected by law? }\end{array}$ & 62 & MEDIUM \\
\hline 11 & $\begin{array}{l}\text { To what extent are discriminatory practices } \\
\text { based on ethnicity, religion, nationality, or } \\
\text { social class against journalists/press } \\
\text { personnel in carrying out their profession? }\end{array}$ & 82 & GOOD \\
\hline 12 & $\begin{array}{l}\text { To what extent do foreign journalists get } \\
\text { permission or access to cover the news? }\end{array}$ & 77 & GOOD \\
\hline 13 & $\begin{array}{l}\text { To what extent is the management of press } \\
\text { companies in this area implemented } \\
\text { transparently and following the public } \\
\text { interest? }\end{array}$ & 71 & GOOD \\
\hline 14 & $\begin{array}{l}\text { To what extent do journalists get a salary } \\
\text { of at least } 13 \text { times the UMP salary in one } \\
\text { year and receive social security for } \\
\text { workers? }\end{array}$ & 64 & MEDIUM \\
\hline 15 & $\begin{array}{l}\text { To what extent do local regulations and } \\
\text { policies in this area encourage local } \\
\text { government officials to comply with legal } \\
\text { obligations to respect and protect press } \\
\text { freedom and provide access for journalists } \\
\text { to report? }\end{array}$ & 67 & MEDIUM \\
\hline 16 & $\begin{array}{l}\text { To what extent do local government } \\
\text { officials carry out their obligations to }\end{array}$ & 71 & GOOD \\
\hline
\end{tabular}

19 Idris, 'Pers Dalam Wacana Hukum (Kajian Tentang Kebebasan,Tanggungjawab, Dan Deviasi Pers Dalam Perspektif Hukum Islam Dan Hukum Positif Di Indonesia'.

${ }^{20}$ Dutta and Roy, 'The Interactive Impact of Press Freedom and Media Reach on Corruption'. 


\begin{tabular}{|c|l|l|l|}
\hline & $\begin{array}{l}\text { respect press freedom and protect } \\
\text { professional press workers? }\end{array}$ & & \\
\hline 17 & $\begin{array}{l}\text { To what extent do local governments use } \\
\text { national security reasons, public order, } \\
\text { public morals, and customary rules to } \\
\text { prevent and limit journalists' coverage? }\end{array}$ & $\mathbf{6 4}$ & MEDIUM \\
\hline
\end{tabular}

Of the 17 (seventeen) main indicators as parameters for legal protection for journalists, the situation in Palu City shows that legal protection for journalists is quite positive, with an average score of 71.18 (good). Of the 17 (seventeen) main indicators as parameters for legal protection for journalists, 1 indicator obtained a poor average score, 7 indicators obtained a moderate average score, 8 indicators obtained a good average score, and 1 indicator obtained a good average score. Get a very good average score.

The condition of the Legal Protection Index for journalists from 2018 to 2019, apart from being reflected in the scores given by expert informants when filling out questionnaires, was also reflected in the FGD process. In general, expert informants are always optimistic about legal protection for journalists for press freedom in Central Sulawesi Province, but at the same time, they are also pessimistic about the problems of the previous year, which tend not to experience improvement/increase. Whereas the press as one of the pillars of democracy can function optimally if the freedom and independence of the press are guaranteed by law.

Threats to press freedom and independence do not always come from the state sector. In questionnaires and through FGDs, informants focused on the conditions and situations that occurred from 2008 to 2019 against threats of intimidation, pressure, and physical violence in various forms by non-state forces to influence or because of the news content. According to the informant, journalists often face threats to the independence and freedom of journalists when carrying out their journalistic duties. In dealing with these threats, journalists feel that they do not get legal protection from security forces or law enforcement officers. One of the press companies in Palu City was once subjected to customary sanctions in the form of givu by a traditional institution because it was deemed to have violated customary law, namely salambibi (washing lips) due to the news about one of the officials in Palu City. According to the informant, Law Number 40 of 1999 concerning the Press has provided legal means that can be taken to give responses or rebuttals to reports in the form of facts or correct incorrect information provided by the press. Such matters require attention to be further regulated in-laws and regulations as well as commitments from the government, law enforcement officers/security forces ${ }^{21}$. The press as a vehicle for mass communication, disseminating information, and forming opinions must be able to carry out the principles, functions, rights, obligations, and roles as well as possible based on professional press freedom so that they must receive legal guarantees and protection, and are free from interference and coercion from anywhere.

In addition to guarantees for the freedom and independence of journalists, legal protection is also related to aspects of journalists' welfare, especially the guarantee of wages equivalent to the Provincial Minimum Wage given by press companies to journalists. The FGD revealed that not all press companies pay their journalists 13 times a year and equal to the provincial minimum wage (UMP). This is adjusted to the financial condition of press companies, especially after the disaster that occurred in 2018. Journalists' salaries should be subject to the provisions of the Manpower Act and guaranteed protection for occupational safety and health.

\section{Analysis Of Enforcement Of The Journalistic Code Of Conduct For Journalists In The City Of Palu}

The Journalistic Code of Ethics reflects the balance between freedom and the social responsibility of the press. The balance between freedom and the social responsibility of the press is important. If it is associated with the theories of the press system, this balance can be achieved by combining the positive aspects of each press theory. If this is done, at least six principles can serve as guidelines for the press: (a). The principle of media freedom; (b). Anti-censorship principle; (c). The principle of social responsibility; (d). The principle of limitation of ownership; (e). The principle of professional protection; (f). The principle of protection of individual rights ${ }^{22}$.

The Journalistic Code of Ethics is a set of professional journalistic ethics compiled by press organizations facilitated and determined by the Press Council. The journalistic code of ethics needs to be enforced, and its implementation is monitored to ensure journalists' professionalism. To guarantee press freedom and fulfill the public's right to obtain correct information, Indonesian journalists need a moral and professional ethical foundation as operational guidelines in maintaining public trust and upholding integrity and professionalism. On that basis, Indonesian journalists establish and adhere to the Journalistic Code of Ethics:

1. Indonesian journalists are independent, produce accurate, balanced news, and do not have bad intentions.

2. Indonesian journalists take professional methods in carrying out their journalistic duties.

3. Indonesian journalists always test information, report in a balanced manner, do not mix judgmental facts and opinions and apply the presumption of innocence.

4. Indonesian journalists do not make false, slanderous, sadistic, and obscene news.

\footnotetext{
${ }^{21}$ Haugabrooks and House-Knight, 'Laws and Regulations'.
}

${ }^{22}$ Armansyah, Pengantar Hukum Pers. 
5. Indonesian journalists do not mention and broadcast the identities of victims of immoral crimes and do not mention the identities of children who are perpetrators of crimes.

6. Indonesian journalists do not abuse their profession and do not accept bribes.

7. Indonesian journalists have the right to refuse to protect sources whose identity or whereabouts are not known, respect the provisions of the embargo, background information, and "off the record" following the agreement.

8. Indonesian journalists do not write or broadcast news based on prejudice or discrimination against someone based on differences in ethnicity, race, skin color, religion, gender, and language and do not demean the weak, poor, sick, mentally disabled or physically disabled.

9. Indonesian journalists respect the rights of sources regarding their private lives, except for the public interest.

10. Indonesian journalists immediately retract, rectify, and correct the false and inaccurate news accompanied by apologies to readers, listeners, and viewers.

11. Indonesian journalists serve the right of reply and right of correction proportionally ${ }^{23}$.

Ethics contains professional morals, which thus does not require "uitwendig" regulations from humans, but rather asks the journalists' "gezinheid". He does not question the existence of outside forces that can assert his will against these journalists, as is the case with the law, but binds them with their own will. As a moral profession it is autonomous, rooted in its human conscience, and derived from its inner strength. ${ }^{24}$ In essence, the code of ethics is made by, from, and for journalists. The journalistic code of ethics does not exist in a vacuum and is value-free, so it must be actualized in real practice in journalism.

The analysis of the index of the enforcement of the journalistic code of ethics for journalists in Palu City was obtained from a survey of 11 informants who had been asked to assess 34 (thirty-four) indicators, and the results of filling out the questionnaire were recapitulated to obtain an average score per indicator. These indicators determine the index of the enforcement of the journalistic code of ethics. The following describes descriptively for the average score given by expert informants related to legal protection for journalists in Palu City in 34 (thirty-four) indicators.

\begin{tabular}{|c|l|c|c|}
\hline NO & \multicolumn{1}{|c|}{ INDICATOR } & $\begin{array}{c}\text { AVERAGE } \\
\text { VALUE }\end{array}$ & INFORMATION \\
\hline 1 & $\begin{array}{l}\text { To what extent do you understand } \\
\text { and apply the meaning of } \\
\text { objectivity in reporting? }\end{array}$ & 77 & GOOD \\
\hline
\end{tabular}

${ }^{23}$ Dewan Pers, Buku Saku Wartawan.

${ }^{24}$ Siregar, Setengah Abad Pergulatan Etika Pers.

\begin{tabular}{|c|c|c|c|}
\hline 2 & $\begin{array}{l}\text { To what extent do you understand } \\
\text { and apply accurate terms in a news } \\
\text { story? }\end{array}$ & 84 & GOOD \\
\hline 3 & $\begin{array}{l}\text { What are your reasons for writing } \\
\text { pseudonyms for rape victims or } \\
\text { children who have experienced } \\
\text { violence? }\end{array}$ & 86 & GOOD \\
\hline 4 & $\begin{array}{l}\text { To what extent do you apply the } \\
\text { importance of showing your } \\
\text { identity to the interviewee before } \\
\text { conducting an interview? }\end{array}$ & 91 & VERY WELL \\
\hline 5 & $\begin{array}{l}\text { To what extent do you understand } \\
\text { the importance of balanced } \\
\text { coverage (Cover Both Side) and } \\
\text { apply it in journalistic work? }\end{array}$ & 78 & GOOD \\
\hline 6 & $\begin{array}{l}\text { To what extent do you understand } \\
\text { the rights of resource persons who } \\
\text { are victims of violence to be } \\
\text { respected? }\end{array}$ & 83 & GOOD \\
\hline 7 & $\begin{array}{l}\text { To what extent do you respect the } \\
\text { personal space of the interviewee, } \\
\text { both physically and } \\
\text { psychologically? }\end{array}$ & 76 & GOOD \\
\hline 8 & $\begin{array}{l}\text { To what extent do you prioritize } \\
\text { the interests of the community } \\
\text { over the interests of certain } \\
\text { companies/media/groups/groups? }\end{array}$ & 83 & GOOD \\
\hline 9 & $\begin{array}{l}\text { To what extent do you take care } \\
\text { that news about children and } \\
\text { women does not cause harm to } \\
\text { sources or children and women as } \\
\text { a whole? }\end{array}$ & 87 & GOOD \\
\hline 10 & $\begin{array}{l}\text { To what extent do you understand } \\
\text { and apply that journalists do not } \\
\text { include personal opinions in the } \\
\text { news? }\end{array}$ & 79 & GOOD \\
\hline 11 & $\begin{array}{l}\text { To what extent did you receive } \\
\text { facilities and envelopes and travel } \\
\text { from the resource persons? }\end{array}$ & 62 & MEDIUM \\
\hline 12 & $\begin{array}{l}\text { To what extent do you fully follow } \\
\text { the direction of the media owner } \\
\text { during the coverage? }\end{array}$ & 74 & GOOD \\
\hline 13 & $\begin{array}{l}\text { To what extent do you hide the } \\
\text { source's identity because the } \\
\text { person concerned is asking for } \\
\text { protection? }\end{array}$ & 88 & GOOD \\
\hline 14 & $\begin{array}{l}\text { To what extent do you present } \\
\text { images of disaster victims in the } \\
\text { news? }\end{array}$ & 80 & GOOD \\
\hline 15 & $\begin{array}{l}\text { To what extent have you prepared } \\
\text { hidden cameras or prepared } \\
\text { money to obtain information from } \\
\text { sources? }\end{array}$ & 66 & MEDIUM \\
\hline 16 & $\begin{array}{l}\text { To what extent do you think and } \\
\text { practice that it is normal to share } \\
\text { the news with other journalists? }\end{array}$ & 55 & BAD \\
\hline 17 & $\begin{array}{l}\text { To what extent do you understand } \\
\text { that journalists should not abuse } \\
\text { their profession and accept bribes? }\end{array}$ & 89 & GOOD \\
\hline 18 & $\begin{array}{l}\text { How far do you understand the } \\
\text { importance of a journalist's good } \\
\text { faith in making news? }\end{array}$ & 81 & GOOD \\
\hline 19 & $\begin{array}{l}\text { To what extent do you understand } \\
\text { that journalists should not hide } \\
\text { important information that the } \\
\text { public needs to know? }\end{array}$ & 82 & GOOD \\
\hline 20 & $\begin{array}{l}\text { To what extent do you avoid } \\
\text { prejudice in your search for news? }\end{array}$ & 79 & GOOD \\
\hline 21 & $\begin{array}{l}\text { To what extent do you reject the } \\
\text { dual task of looking for news and }\end{array}$ & 62 & MEDIUM \\
\hline
\end{tabular}

Page 565 


\begin{tabular}{|c|c|c|c|}
\hline & $\begin{array}{l}\begin{array}{l}\text { advertisements as part of } \\
\text { journalist's job? }\end{array} \\
\text { a }\end{array}$ & & \\
\hline 22 & $\begin{array}{l}\text { To what extent do you refuse } \\
\text { pocket money from sources? }\end{array}$ & 79 & GOOD \\
\hline 23 & $\begin{array}{l}\text { To what extent do you not present } \\
\text { news that smacks of obscenity, } \\
\text { cruelty, and sexual violence? }\end{array}$ & 85 & GOOD \\
\hline 24 & $\begin{array}{l}\text { To what extent do you understand } \\
\text { the difference between the right of } \\
\text { reply and the right of correction? }\end{array}$ & 84 & GOOD \\
\hline 25 & $\begin{array}{l}\text { To what extent have you } \\
\text { responded proportionally to the } \\
\text { right of reply and the right to } \\
\text { correct the injured parties and } \\
\text { have an interest in the news? }\end{array}$ & 89 & GOOD \\
\hline 26 & $\begin{array}{l}\text { To what extent have you removed, } \\
\text { corrected, and corrected the false } \\
\text { and inaccurate news and followed } \\
\text { it up with a formal apology? }\end{array}$ & 85 & GOOD \\
\hline 27 & $\begin{array}{l}\text { To what extent do you include } \\
\text { news covered in advertisements in } \\
\text { the news? }\end{array}$ & 68 & MEDIUM \\
\hline 28 & $\begin{array}{l}\text { To what extent do you respect the } \\
\text { embargo from the source? }\end{array}$ & 84 & GOOD \\
\hline 29 & $\begin{array}{l}\text { To what extent do you uphold the } \\
\text { principle of the presumption of } \\
\text { innocence in reporting? }\end{array}$ & 84 & GOOD \\
\hline 30 & $\begin{array}{l}\text { To what extent do you place the } \\
\text { vulnerable parties in the same } \\
\text { position from the reporting point } \\
\text { of view? }\end{array}$ & 83 & GOOD \\
\hline 31 & $\begin{array}{l}\text { To what extent you have } \\
\text { implemented } \\
\text { commitments } \\
\text { off-the-record } \\
\text { persons? }\end{array}$ & 89 & GOOD \\
\hline 32 & $\begin{array}{l}\text { To what extent do you reject news } \\
\text { cloning without doing field } \\
\text { coverage? }\end{array}$ & 84 & GOOD \\
\hline 33 & $\begin{array}{l}\text { To what extent do you prioritize } \\
\text { the truth of the news rather than } \\
\text { the sensational element? }\end{array}$ & 83 & GOOD \\
\hline 34 & $\begin{array}{l}\text { To what extent do you prioritize } \\
\text { wisdom in making news to not } \\
\text { have a bad impact on the } \\
\text { community? }\end{array}$ & 86 & GOOD \\
\hline
\end{tabular}

Of the 34 (thirty four) main indicators, it shows thatunderstanding, compliance, and enforcement of the journalistic code of ethics for journalists in Palu Citywhich is quite positive. Of the 34 (thirty four) main indicators as parameters for the enforcement of the journalistic code of ethics for journalists, 1 indicator obtained a poor average score, 4 indicators obtained a moderate average score, 28 indicators obtained a good average score, and 1 indicator gets a very good score.

The Journalistic Code of Ethics enforcement index condition from 2018 to 2019 , besides being reflected in the value given by expert informants when filling out the questionnaire, was also reflected in the FGD process. In general, expert informants are always optimistic about the enforcement of the Journalistic Code of Ethics in Central Sulawesi Province, but several problems related to the enforcement of the journalistic code of ethics are still frequently encountered. The Journalistic Code of Ethics is self-regulation made by Indonesian journalists and stipulated through the Press Council Decree Number 03/SK-DP/III/2006 concerning the Journalistic Code of Ethics which binds/ becomes a rule for journalists in carrying out journalistic tasks.

Through questionnaires and FGD, informants focused on the conditions and situations that occurred between 2008 and 2019, which corresponded to the three (3) indicators that obtained the lowest average score in the index of upholding the journalistic code of ethics. These indicators include the attitude of journalists in receiving facilities and envelopes and roads from sources, and indicators of the philosophy of journalists practicing news sharing with other journalists, the attitude of journalists in carrying out the dual task of seeking news as well as advertising as part of a journalist's job. The practice of receiving facilities and/or envelopes is still often carried out by journalists; however, according to the informant, the facilities provided are usually related to the implementation of journalistic duties, for example, journalists who cover news outside the city are given facilities in the form of airplane tickets or other vehicle facilities by the informants. The practice of sharing news among journalists is still common, thus allowing for duplication of news. Likewise, in the practice of carrying out the dual task of searching for news and advertisements, according to the informant, this may be done as long as information in the form of advertisements must be included in the advertorial category. Besides three (3)With these indicators, several indicators have also become the attention of informants even though they have a fairly good score, including 1) the attitude indicator of journalists places vulnerable parties in the same position from the point of view of reporting.. According to informants, the media tend to only present news about vulnerable groups only in ceremonial activities, such as AIDS day commemoration, etc., but no news makes them subjects by prioritizing the interests of vulnerable groups. 2)an indicator of journalists' understanding and knowledge in using pseudonyms for rape victims or children who have experienced violence. According to the informant, Article 5 of the journalistic code of ethics stipulates that Indonesian journalists do not mention and broadcast the identities of victims of immoral crimes and do not mention the identities of children who are perpetrators of crimes. Identity in question is all data and information concerning a person that makes it easier for others to track. However, journalists often do not understand and implement this principle in reporting. Identity is not understood comprehensively but partially understood that identity is only in the form of a child's name or the name of someone who is a victim of rape or a victim of violence. So that news about acts of child rape is presented only by disguising the child's name without masking other information such as school origin, parents' names, age, and others. 3)indicator of journalists' understanding not to include personal opinions in the news. It was revealed in the forum that journalists understand the prohibition against including personal opinions in the news. However, in practice, there are still many who confuse facts 
with opinions in reporting.. For example, using words such as "sadistic behavior", "very crowded", "a lot", "Looks angry", and so on. However, according to the informant, when using accurate measurements based on observations, it sometimes reaps protests from the public interested in the news. Example: news about the number of participants in running competitions, political party sympathizers, etc. The prohibition of mixing opinions and facts concerns judgmental opinions in the form of journalists' personal opinions, not interpretive opinions, namely opinions in journalists' interpretations of facts.

Enforcement of the journalistic code of ethics is an inseparable part of the freedom of the press. Freedom of opinion, expression, and press are human rights protected by Pancasila, the 1945 Constitution, and the United Nations Universal Declaration of Human Rights. Freedom of the press is a means for the public to obtain information and communicate to fulfill essential needs and improve the quality of human life. In realizing press freedom, Indonesian journalists are also aware of the interests of the nation, social responsibility, community diversity, and religious norms. In carrying out its functions, rights, obligations, and roles, the press respects the human rights of everyone. Therefore the press is required to be professional and open to be controlled by the public. To guarantee press freedom and fulfill the public's right to obtain correct information, Indonesian journalists need a moral and professional ethical foundation as operational guidelines in maintaining public trust and upholding integrity and professionalism. Enforcement of the journalistic code of ethics is the enforcement of professional journalistic ethics. Journalists are members of the press who take part in upholding the pillars of democracy.

\section{CONCLUSION}

From the overall analysis of legal protection and enforcement of the journalistic code of ethics in Palu City, Central Sulawesi Province, it can be concluded several main points as follows:

1. Legal protection for journalists in the city of Palu based on the average value of 17 (seventeen) indicators which become the assessment parameters, is in a good situation with a score of 71.18. The indicator of freedom and independence of journalists in choosing journalists' organizations is in the highest position with a score of 91 (excellent), the indicator of legal protection by law enforcement officers and security forces against journalists from threats of intimidation, pressure, and physical violence is in the lowest position with a score of 53 ( bad). Based on the data obtained by the researcher, it shows that in general, journalists have obtained legal protection for their freedom and independence in carrying out journalistic duties as guaranteed in Article 28 of the Constitution of the Republic of Indonesia, Law Number 40 of 1999 concerning the Press, Law Number 14 of 2008 concerning Public Information Disclosure, as well as other laws and regulations governing legal protection for the press. However, in 2018, there are still frequent threats of violence/intimidation/and harassment against the journalist profession. Perpetrators come from public officials, security forces/law enforcement officers, and the public on behalf of community organizations (Ormas) suspected of having links with public officials in areas that are currently in the spotlight of the news. Threats to the freedom and independence of the press come from the Criminal Code or national laws and regulations and potentially come from customary law. Whereas Law Number 40 of 1999 concerning the Press, it has set the mechanism for resolving press disputes,

2. Enforcement of the journalistic code of ethics for journalists in the city of Palu based on the average value of 34 (thirty-four) indicators that become the assessment parameters is in a good situation with a score of 80.14. The indicator of journalists' understanding of the importance of showing identity to informants before conducting interviews is in the highest position with a score of 91 (very good). The attitude indicator of journalists sharing news with other journalists is in the lowest place with a score of 55 (poor). Based on the data obtained by researchers regarding the enforcement of the journalistic code of ethics for journalists, it shows that in general journalists have complied with the journalistic code of ethics as an ethical guideline and moral foundation in carrying out journalistic tasks, even though in the period 2018 to 2019 several journalists/media showed inappropriate behavior. Not following the journalistic code of ethics. Especially behavior related to journalists' attitudes towards reporting on children/children or women victims of immoral crimes, in reporting often journalists do not hide the overall identity of the victim. Likewise, it was revealed that journalists' behavior was more concerned with company/private interests than public/public interests, for example, conflicts of interest between presenting news products or advertisements (advertorials). Media practices also do not give space to the interests of vulnerable groups. Reporting on vulnerable groups is only ceremonial, not as a subject whose interests are the focus of the news. Informants in the FGDs also focused on the behavior of online media which often ignored the principle of balanced coverage or cover both sides in reporting.

\section{SUGGESTION}

1. Given that threats of violence/intimidation/harassment against the journalist profession are still common, efforts must be made to strengthen the guarantee of legal protection for journalists in the laws and regulations. Likewise, law enforcement officers must be actively committed to protecting journalists in carrying out their journalistic duties. Public officials and political figures should position the press as a partner in realizing transparent and accountable governance, includingincluding the importance of the role of local governments to encourage the professionalism of journalists and 
adherence to the journalistic code of ethics are the most serious things to be reformed. In addition to strengthening the guarantee of legal protection for the freedom and independence of journalists, guarantees for the welfare of journalists also affect the professionalism of journalists in carrying out their journalistic duties.

2. The professionalism of a journalist is determined by the level of obedience to the journalistic code of ethics as a set of professional journalistic ethics. The idea developed in the FGD so that journalists should receive literacy strengthening and increased understanding of the journalistic code of ethics. Press companies are also required to be more active in providing education and training to journalists to improve quality and skills, which will increase the professionalism of journalists in carrying out journalistic tasks.

\section{REFERENCE}

[1] Armansyah. Pengantar Hukum Pers. 1st ed. Bekasi: Gramata Publishing, 2015

[2] Chiang, Frank. 'The State and Sovereignty'. In The One-China Policy: State, Sovereignty, and Taiwan's International Legal Status, 13-99. Elsevier, 2018. https://doi.org/10.1016/B978-0-08102314-3.00002-1.

[3] Congleton, Roger D. 'The Institutions of International Treaty Organizations as Evidence for Social Contract Theory'. European Journal of Political Economy 63 (June 2020): 101891. https://doi.org/10.1016/j.ejpoleco.2020.101891.

[4] Cui, Shujie, and Peng Qi. 'The Legal Construction of Personal Information Protection and Privacy under the Chinese Civil Code'. Computer Law \& Security Review 41 (July 2021): 105560. https://doi.org/10.1016/j.clsr.2021.105560.

[5] Dawson, Andrew. 'The Achilles Heel of Democracy? A Macro Cross-National Assessment of the Correlates of State Legitimacy'. Social Science Research 97 (July 2021): 102574. https://doi.org/10.1016/j.ssresearch.2021.102574.

[6] Dewan Pers. Buku Saku Wartawan. 7th ed. Jakarta: Dewan Pers, 2017.
[7] Dutta, Nabamita, and Sanjukta Roy. 'The Interactive Impact of Press Freedom and Media Reach on Corruption'. Economic Modelling $58 \quad$ (November 2016): 227-36. https://doi.org/10.1016/j.econmod.2016.05.008.

[8] Fajar ND, Mukti, and Yulianto Achmad. Dualisme Penelitian Hukum Normatif \& Empiri. Yogyakarta: Pustaka Pelajar, 2010.

[9] Haugabrooks, Esther M., and Tamara House-Knight. 'Laws and Regulations'. In Information Resources in Toxicology, 815-27. Elsevier, 2020. https://doi.org/10.1016/B978-0-12-8137246.00073-6.

[10] Idris. 'Pers Dalam Wacana Hukum (Kajian Tentang Kebebasan,Tanggungjawab, Dan Deviasi Pers Dalam Perspektif Hukum Islam Dan Hukum Positif Di Indonesia'. Al Ihkam: Jurnal Hukum \& Pranata Sosial 2, no. 5 (2012).

[11] Judhariksawan. Hukum Penyiaran. Jakarta: Rajawali Press, 2010.

[12] Kemendibud. Kamus Besar Bahasa Indonesia Daring Kemendikbud. Accessed 17 October 2019. https://kbbi.kemdikbud.go.id/entri/pers.

[13] Kerjasama dengan Fakultas Hukum Universitas Tadulako. Survei Sulawesi Tengah. Sulawesi Tengah, 2017.

[14] Manan, Bagir. 'Pers Bermutu'. Dewan Pers 2013 (blog), 2013. www.dewanpers.or.id.

[15] Mochtar, Zainal Arifin. Lembaga Negara Independen: Dinamika Perkembangan Dan Urgensi Penataannya Kembali PascaAmandemen Konstitus. 1st ed. Jakarta: Rajawali Pers, 2016.

[16] Siregar, R.H. Setengah Abad Pergulatan Etika Pers. Jakarta: Dewan kehormatan PWI, 2005.

[17] Susanto, Edy. Hukum Pers Di Indonesia. Jakarta: Rineka Cipta, 2010.

[18] Tim Peneliti Dewan Pers. Indeks Kemerdekaan Pers Tahun 2016. Jakarta: Dewan Pers, 2016. Indeks Kemerdekaan Pers Tahun 2017. Jakarta: Dewan Pers, 2017. Indeks Kemerdekaan Pers Tahun 2018. Jakarta: Dewan Pers, 2018.

[19] Undang-Undang. Nomor 40 Tahun 1999 tentang Pers, Pub. L. No. Konsideran MenimBang huruf c (1999).

[20] Wang, Yuanni, Hailin Cao, Yingchun Yuan, and Ruilian Zhang. 'Empowerment through Emotional Connection and Capacity Building: Public Participation through Environmental NonGovernmental Organizations'. Environmental Impact Assessment $\begin{array}{lllll}\text { Review } & 80 & \text { (January 2020): } & 106319 .\end{array}$ https://doi.org/10.1016/j.eiar.2019.106319. 